\title{
Introduction to part $\mathrm{V}$
}

\author{
Chris Zielinski \\ Vice-Chair \\ IFIP WG 9.2 \\ zielinskic@who.int
}

This chapter seeks to draw lessons from the World Summit on the Information Society (WSIS), a two-stage summit spread over 18 months, which had unique aspects in its structure and process, notably the prominent role played by civil society, and the resultant "action lines" which are being actively pursued as this book is being published.

In the first of the two papers presented here, Prof Yves Poullet looks at what we mean by "Internet governance" and why efforts are being made to establish a regulatory framework. Considering how the topic of Internet governance is treated in the WSIS documentation and conclusions, he identifies new WSIS principles on Internet governance that have emerged. The tensions between technical and legal aspects are noted including certain ambiguities. He considers the differing pulls of the multistakeholder concept - how the intergovernmental organizations (notably ITU, UNESCO, WIPO and WTO), the private groupings with international scope (such as ICANN), and civil society have had their agendas in this domain weakened, strengthened or otherwise adjusted. He looks at how well has participatory democracy been served by the creation of such bodies as the Internet Governance Forum, and commends WSIS for its role in trying to ensure that the process is one of pro-active participatory democracy open to all stakeholders.

In looking forward towards a new regulatory framework, he considers key legal and regulatory aspects include self-regulation and co-regulation., and considers if the European model can provide a solution, commending such cornerstone EU concepts as subsidiarity and proportionality and showing how they fit with the WSIS conclusions.

In conclusion, Prof Poullet notes that the international governance of the Internet must correspond to the international dimension of the network. This perspective explains and justifies the WSIS efforts to propose a global Constitution for Cyberspace, as a single document uniting all aspects of Internet governance. But he questions if international public organisations are ready to assume this responsibility, noting that private international organisations have grown rapidly, and have 
developed a shadowy world of standards and technical norms. Moreover these private international institutions are operating the infrastructure. Civil society is also growing in stature and capacity, although it lacks effective representative bodies. $\mathrm{He}$ feels a new democratic process is needed at the international level.

Prof. Jacques Berleur focuses on the societal and ethical consequences of the WSIS action lines, which he divides into basic issues (such as justice, human dignity and other human rights aspects), issues related closely to information and communication technologies (ICTs), and reflects on the means to ensure that societal and ethical concerns are addressed and respected.

Regarding societal and ethical aspects of ICTs, Prof Berleur notes that the valuebase of the information society must be founded on the principles contained in the ensemble of internationally agreed-upon conventions, declarations, and charters. More specifically, there should be equal, fair and open access to knowledge and information resources.

A second issue is that appropriate actions and preventive measures, as determined by law, should be taken against abusive uses of ICTs, such as illegal and other acts motivated by racism, racial discrimination, xenophobia, and related intolerance, hatred, violence, all forms of child abuse, including paedophilia and child pomography, and trafficking in, and exploitation of, human beings.

Relevant stakeholders, especially in academia, should continue research on ethical dimensions of ICTs. The independence, pluralism and diversity of media, and freedom of information should be respected, and work in societal spheres should always include the principles of trust, stewardship and shared responsibility together with digital solidarity.

$\mathrm{He}$ stresses that Codes of ethics and standards should be adopted and mechanisms should be established to monitor their application as well as providing appropriate sanctions for their violation. He concludes that respect for diversity must be a central criterion in establishing the principles and mechanisms for resolving conflicts that arise in information societies.

Prof Berleur proposes "the re-creation of public spaces", as a mediation between theory and practice, expertise and application, where there could be real "deliberation" (more than a negotiation) before the decision-making. A second step to confront emerging societal and ethical problems of the Information Society is to try to anticipate the social and ethical risks, and take appropriate measures while there is still time to do so.

In considering the agenda of the Internet Governance Forum, he suggests a number of issues that could be developed in the framework of the agenda of the IGF to come. Following the categorization he had used in an earlier publication, Prof Berleur divided the social and ethical issues arising in connection with WSIS to be those related to 1) technical governance (DNS issue, respect for national legislative diversity, role of private organisations in societal decision-making, role of ICANN, limits and validity of technical norms), 2) self-regulation (its place in the normative order, normative roles of private actors and regulators, future of democracy, etc.), and 3) the regulation of the Internet and of the Information Society (the lack of transparency, predominance of vested interests, lack of real democratic process or real ethical concern, who is controlling ethics an democracy?). 
He concludes that there remains "a lot of work to be done" to build an ethically responsible and socially conscious Information Society. 